\title{
Environmental Characteristics of the Cemeteries of Buenos Aires City (Argentina) and Infestation Levels of Aedes aegypti (Diptera: Culicidae)
}

\author{
Darío Vezzani ${ }^{+}$, Stella M Velázquez, Silvina Soto, Nicolás J Schweigmann
}

Grupo de Estudio de Mosquitos, Facultad de Ciencias Exactas y Naturales, Universidad de Buenos Aires, Ciudad Universitaria, Pabellón II, $4^{\circ}$ piso, 1428 Buenos Aires, Argentina

Cemeteries with many water-filled containers, flowers, sources of human blood, and shade are favorable urban habitats for the proliferation of Aedes aegypti, a vector of yellow fever and dengue. A total of 22,956 containers was examined in the five cemeteries of the city of Buenos Aires, Argentina. The vector was found in four cemeteries that showed an average infestation level of 5.5\% (617 positive out of 11,196 water-filled containers). The four cemeteries positive for Ae. aegypti showed significantly different $(p<0.01)$ infestation levels. Vegetation cover and percentage of infestation were significantly correlated $(p<0.01)$, but neither cemetery area nor number of available containers were significantly related to the proportion of positive vases. Our results suggest that the cemeteries of Buenos Aires represent a gradient of habitat favorableness for this vector species, some of which may act as foci for its proliferation and dispersal.

Key words: Aedes aegypti - cemeteries - vegetation cover - container availability - dengue - Buenos Aires Argentina

Aedes (Stegomyia) aegypti (L.), vector of yellow fever and dengue, was considered to be eradicated from Argentina during the Anti-aegypti Campaign in 1963 (Carcavallo 1968). However, this species was again detected in 1986 in the northeastern region of the country. In 1991 it reappeared in the Province of Buenos Aires (Campos 1993), at the southern limit of its distribution (Sabattini et al. 1998). Its presence in the capital city was demonstrated in 1995 (Junín et al. 1995), where a generalized infestation was recorded throughout the city only one year later (Schweigmann et al. 1996).

The expansion of the zones of transmission of the dengue virus towards the south of the continent has increased the risk of infection in Argentina (Avilés et al. 1999). The most recent epidemics were recorded in 1998 in the Province of Salta (Argentina) and in some cities close to the eastern most borders of the country: Foz de Iguaçu (Brazil) in 1998 and Asunción (Paraguay) in 1999 (Boffi Rolando 1999 pers. commun.).

According to Service (1992), there has been more written on the biology of Ae. aegypti than

\footnotetext{
$\overline{{ }^{+} \text {Corresponding author. Fax: }}$ +54-11-4373-6102. E-mail: nicolas@bg.fcen.uba.ar Received 27 June 2000 Accepted 18 January 2001
}

any other mosquito, but there have actually been relatively few good ecological studies on this species. On the other hand, very little is known on the ecology of this vector at the southern limit of its distribution.

The preimaginal stages of this mosquito develop in artificial containers of small volume, such as flasks, bottles, and flower vases (Christophers 1960). The adults feed on nectar depending on its availability (Martinez-Ibarra et al. 1997), whereas the females need to ingest blood to oviposit (Clements 1992). They select shaded places and dumps for resting and ovipositing (PAHO 1995). Cities usually meet the habitat requirements of $A e$. aegypti, but at any given place the habitat quality will depend on the fact that some of these factors (nectar, blood, and suitable places for resting and ovipositing) may be limiting to this species.

Cemeteries in particular have a high number of water-filled containers, flowers, few buildings surrounded by vegetation, and permanent sources of human blood (visitors and workers). These characteristics render cemeteries as urban habitats favorable for Ae. aegypti. Studies carried out in cemeteries of Florida (O'Meara et al. 1992), Manila (Schultz 1989), and Caracas (Barrera-R et al. 1980) have demonstrated the presence of elevated levels of infestation of this vector.

As a consequence of an accelerated and unplanned urbanization, at present the cemeteries of Buenos Aires are located within densely populated neighborhoods. City cemeteries may act as foci for 
the proliferation of Ae. aegypti; thus influencing the infestation levels of adjacent zones.

Our study was aimed at evaluating the effects of container density, site area, vegetation cover, and cleanness of the environment on the infestation levels of Ae. aegypti in the cemeteries of Buenos Aires city.

\section{MATERIALS AND METHODS}

Study area - The present study was carried out in the five cemeteries of the city of Buenos Aires (Fig. 1A). Three of them (BR: Británico, AL: Alemán, and $\mathrm{CH}$ : Chacarita) are contiguous and located in a quarter of high buildings and great commercial activity. The other two: Flores (FL) and Recoleta (RE), are $8 \mathrm{~km}$ apart, and at $6 \mathrm{~km}$ from the previously mentioned three. FL is located in a quarter where houses are the predominant type of building, whereas RE lies in a residential zone of high purchasing power.

$\mathrm{BR}$ and $\mathrm{AL}$ cemeteries belong to the British and German communities respectively. The vegetation of these private parks is carefully cared for and the flower vases recharged with water very often. In contrast, the other three cemeteries $(\mathrm{CH}$, FL, and RE) are public (run by municipal authorities) and have sections that are poorly cared for and improperly cleaned.

Buildings (surfaces covered by a roof and having interior rooms) within the cemeteries are scarce or non-existent in BR and $\mathrm{AL}$, more common in $\mathrm{FL}$, and frequent in RE. The greatest environmental heterogeneity occurs in $\mathrm{CH}$, which encompasses both open fields and buildings up to two stories high with up to four underground levels. Walls (4 to $10 \mathrm{~m}$ high) surround all five cemeteries except for a wire fence, partially covered by vegetation, that separates BR from AL.

Methodology - From January through April 1998,80 to 400 containers per hectare were examined in each cemetery. The water in each container was filtered with a fine mesh strainer. All preimaginal mosquitoes collected were fixed in 70\% ethanol. Immature Ae. aegypti were identified according to the key for Argentine mosquitoes (Darsie 1985). The frequency of occurrence of other mosquito species was not assessed.

Container availability (density per hectare) was calculated by surveying all the containers present in each cemetery. Vegetation cover was estimated from digitized aerial photographs taken in 1998 (1:15000, Instituto Geográfico Militar). All nonvegetation landscape elements were eliminated from the images by means of a digital filter (Fig. 1C), and the area occupied by plants computed.

Data analysis - The infestation levels of Ae. aegypti in each cemetery were calculated as the percentage of positive containers out of the number of water-filled containers (potential breeding sites). Infestation differences among cemeteries were evaluated by means of a gradient analysis of proportions for quantitatively ordered samples (Fleiss 1981).

The relationship between the observed infestation levels and the studied environmental variables (site area, number of available containers, and vegetation cover) was analyzed through regression, by means of GLIM (generalized linear model), adjusting the error to a binomial distribution (Crawley 1993).

\section{RESULTS}

The number of containers surveyed in the 99 hectares occupied by the five cemeteries was 153,431 . Out of 22,956 containers examined, $49 \%$ $(11,196)$ were water-filled. Ae. aegypti was present in four out of the five cemeteries (Table). These four cemeteries had significantly different $(\mathrm{p}<0.01)$ proportions of positive containers $(\mathrm{BR}>\mathrm{AL}>$ $\mathrm{CH}>\mathrm{FL}$ ). The mean infestation level of Ae. aegypti in the five cemeteries was $5.5 \%$ (617 positive containers/11,196 water-filled containers). Other larval culicids found were: Culex pipiens Linnaeus, 1758, Cx. eduardoi Casal \& García 1968, and $C x$. mollis Dyar \& Knab, 1906.

The three contiguous cemeteries (Fig. 1A) had the highest frequencies of Ae. aegypti. However, the highest level of significant difference $(\mathrm{p}<0.001)$ in infestation was found between private $(\mathrm{BR}+\mathrm{AL}$ : $19 \%, 518 / 2,710)$ and public cemeteries $(\mathrm{CH}+\mathrm{FL}$ : $1 \%, 99 / 8,447)$.

Container density per hectare (Table) versus infestation level did not yield a significant regression ( $\left.p>0.05, \mathrm{VC}=0.02, \mathrm{~F}_{1,3}=10.13\right)$, even though container availability was at least eight times higher in vector positive cemeteries than in the only cemetery where the vector was not found. The area occupied by each cemetery (Table) was not significantly related to differences in the infestation levels $\left(\mathrm{p}>0.05, \mathrm{VC}=7.84, \mathrm{~F}_{1,3}=10.13\right)$.

The vegetation cover estimated from Fig. 1C showed a gradient that ranges from a maximum of $82 \%$ (BR) to a minimum of $5 \%$ (RE). This single variable explained $96.8 \%(\mathrm{p}<0.01, \mathrm{VC}=90.4$, $\left.\mathrm{F}_{1,3}=34.12\right)$ of the variation in the infestation levels (Fig. 1B).

\section{DISCUSSION}

The maximum percentages of breeding sites $(10.2$ and $25 \%)$ in the two most infested cemeteries of Buenos Aires were higher than the mean value $(5.9 \%)$ recorded in houses of this city (Cardinal et al. 2000). These cemeteries are located within a densely urbanized district, only $400 \mathrm{~m}$ 


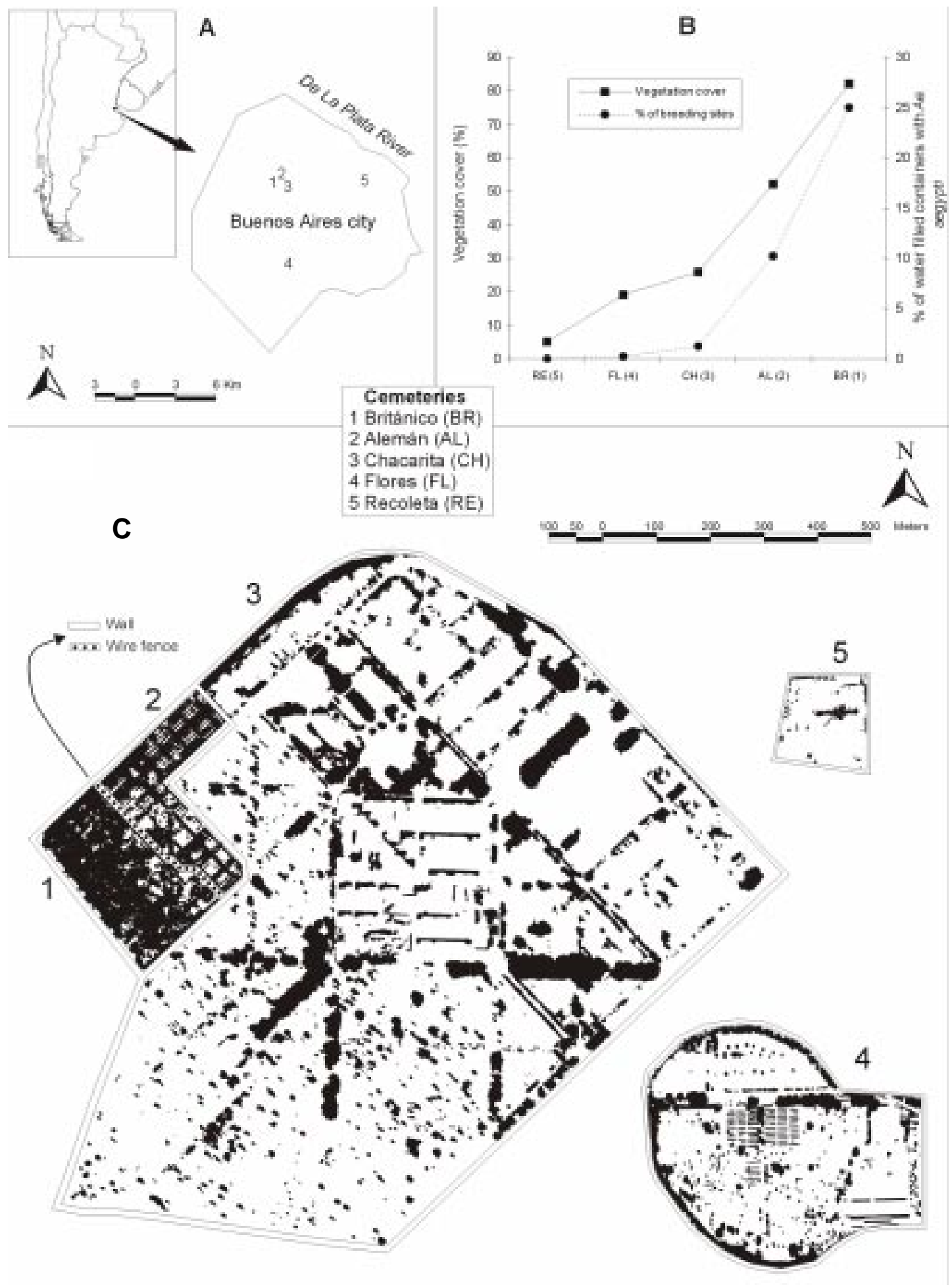

Fig. 1-A: geographic location of the five cemeteries of the city of Buenos Aires (Argentina); B: variations in vegetation cover and percentage of containers positive for Aedes aegypti among cemeteries; C: digital images obtained from aerial photographs (scale 1:15,000); the dark zones represent vegetation. 
TABLE

Cemeteries of the city of Buenos Aires, number of containers examined, percentage infestation of Aedes aegypti, container density, and cemetery area

\begin{tabular}{lccrr}
\hline Cemetery & $\begin{array}{c}\text { Containers } \\
\text { examined }\end{array}$ & $\begin{array}{c}\text { Percentage infestation } \\
\text { (positive containers/water-filled containers) }\end{array}$ & $\begin{array}{c}\text { Container density } \\
\text { (containers/ha) }\end{array}$ & $\begin{array}{c}\text { Area } \\
\text { (ha) }\end{array}$ \\
\hline Británico & 2,175 & $25 \%(409 / 1,637)$ & 1,499 & 5 \\
Alemán & 1,212 & $10.2 \%(109 / 1,073)$ & 1,958 & 3 \\
Chacarita & 17,857 & $1.3 \%(97 / 7,544)$ & 1,440 & 72 \\
Flores & 1,355 & $0.22 \%(2 / 903)$ & 2,120 & 17 \\
Recoleta & 357 & $0 \%(0 / 39)$ & 179 & 2 \\
\hline
\end{tabular}

distant from an important hospital (Tornú). Our results suggest that the cemeteries of Buenos Aires may act as important foci of proliferation of the vector, thus increasing the risk of disease transmission within their neighborhoods.

Although container availability was not significantly correlated with infestation level, it is reasonable to infer that a higher number of water-filled containers would favor mosquito populations by increasing the number of potential breeding sites. In that respect, Tinker (1964), found a positive association between the infestation levels and the density of containers per house. Nevertheless, that study refers to houses where average container density was less than two. In cemeteries having more than 1,000 containers per hectare, we may assume that breeding sites would not be a limiting factor for the proliferation of Ae. aegypti.

Our results failed to show an association between the proportion of positive containers and cemetery area, although a large cemetery with a low infestation level (e.g. CH: $1 \%, 72$ ha) may still yield enough adults to be of epidemiological importance.

The vegetation cover was the only variable significantly related to the observed differences in infestation levels among the five cemeteries. Although we cannot assess the effect of variables that have not been considered in this work, a $96.8 \%$ correlation suggests that vegetation should be related to infestation levels in the surveyed cemeteries.

The vegetation provides shade and plant debris to flower vases (Schultz 1989), thus improving the quality of these microhabitats as potential breeding sites for mosquitoes. In a cemetery of Caracas (Venezuela), Barrera-R et al. (1980) found that Ae. aegypti prefer shaded containers. In studies carried out in houses of Thailand, sheltered containers located in the shade were more positive for Ae. aegypti, probably owing to the preference of ovipositing females for these kind of habitats (Kittayapong \& Strickman 1993). Similarly, Tun-
Lin et al. (1995) concluded that shaded patios in Australia yielded 2.6 times more positive containers than those exposed to the sun.

Air temperature and relative humidity are essential factors for the survival of adult mosquitoes, whereas water temperature is important to larvae (Fay 1964). In this sense, the shade provided by the vegetation would buffer extreme values of temperature and humidity, thus increasing the survival of both adults and larvae during the summer, with the consequent rise of the infestation levels.

On the other hand, eggs sheltered from the low winter temperatures have a higher chance of survival (Bond et al. 1970). The microclimatic conditions generated by the presence of vegetation may reduce egg mortality during the winter, allowing a fast recovery of the vector population starting from a higher number of surviving eggs.

The behavior of Ae. aegypti may vary among different regions (Forattini 1965). Tun-Lin et al. (1995) determined that untidy and dirty sites were 2.5 times more infested than tidier and cleaner ones. By contrast, our results indicate that the infestation rate in the tidier cemetery (BR) was 19.2 times higher than in the less tidy one $(\mathrm{CH})$. However, the individual effects of cleanliness and shade provided by vegetation cannot be easily discriminated.

Great differences in the infestation levels of contiguous areas, such as the one observed between $\mathrm{BR}$ and $\mathrm{CH}$, besides indicating notable contrasts in habitat quality, suggest that dispersal between areas was very low. Female dispersal may be determined by the availability of suitable oviposition sites, with minimum values at high container availability (Reiter 1996). The wall that separates these cemeteries may act as an efficient barrier between both populations of the vector.

Overall, our results suggest that the studied cemeteries exhibit a gradient of habitat quality correlated with vegetation cover. These variable conditions might favor different behaviors in the populations of Ae. aegypti present in Buenos Aires. 


\section{ACKNOWLEDGEMENTS}

To the members of the Grupo de Estudios de Mosquitos de la Universidad de Buenos Aires, serving the Government of the city of Buenos Aires, for their help with the field work; to Lic Aníbal Carbajo for his collaboration with the statistical analysis.

\section{REFERENCES}

Avilés G, Rangeón G, Vorndam V, Briones A, Baroni P, Enria D, Sabattini MS 1999. Dengue reemergence in Argentina. Emerg Infecs Dis 5: 575-578.

Barrera-R R, Machado-Allison CE, Bulla LA 1980. Criaderos, densidad larval y segregación de nicho en tres Culicidae urbanos (Culex fatigans Wied., $C$. corniger Theo. y Aedes aegypti L.) en el cementerio de Caracas. Acta Cient Venezolana 30: 418-424.

Bond HA, Keirans JE, Babbitt MF 1970. Environmental influences on the viability of overwintering Aedes aegypti (L.) eggs. Mosq News 30: 528-533.

Campos RE 1993. Presencia de Aedes (Stegomyia) aegypti L. (Diptera: Culicidae) en la localidad de Quilmes (Buenos Aires, Argentina). Rev Soc Entomol Argent 52: 36.

Carcavallo RU 1968. Fiebre amarilla, vectores y cadena epidemiológica. Cap III. Com Invest Cientif Prov Buenos Aires 1: 105-114.

Cardinal MV, Lanati LA, Rubio A, Kuruc JA, Hernández Penna S, Mazzone G, Albioni GE, Gutierrez ML, Reichmann L, Iturriaga M, Dure Ruiz NM, Pirk GI, Schweigmann N 2000. Infestación domiciliaria por formas inmaduras de Aedes aegypti (Diptera: Culicidae) en la Capital Federal. Jornada Regional Sobre Mosquitos, Buenos Aires, Argentina, p. 66-67.

Christophers R 1960. Aedes aegypti (L.), the Yellow Fever Mosquito, Cambridge Univ Press, Cambridge, $739 \mathrm{pp}$.

Clements AN 1992. The Biology of Mosquitoes, Chapman \& Hall, London, 509 pp.

Crawley MJ 1993. Methods in Ecology: GLIM for Ecologists, Blackwell Scientific Publication, Oxford, 379 pp.

Darsie Jr RF 1985. Mosquitoes of Argentina. Part I. Keys for identification of adult females and fourth stage larvae in English and Spanish (Diptera, Culicidae). Mosq Syst 17: 153-253.

Fay RW 1964. The biology and bionomics of Aedes aegypti in the laboratory. Mosq News 24: 3.

Fleiss JL 1981. Statistical Methods for Rates and Proportions, John Wiley \& Sons, USA, 255 pp.
Forattini OP 1965. Entomología Médica. 2. Culicini: Culex, Aedes e Psorophora, Ed. Univ. São Paulo, São Paulo, 506 pp.

Junín B, Grandinetti H, Marconi JM, Carcavallo RU 1995. Vigilancia de Aedes aegypti (L) en la ciudad de Buenos Aires (Argentina). Entomol y Vect 2: 7175.

Kittayapong P, Strickman D 1993. Distribution of container-inhabiting Aedes larvae (Diptera: Culicidae) at a dengue focus in Thailand. J Med Entomol 30: 601-606.

Martinez-Ibarra JA, Rodriguez MH, Arredondo-Jiménez JI, Yuval B 1997. Influence of plant abundance on nectar feeding by Aedes aegypti (Diptera: Culicidae) in southern Mexico. J Med Entomol 34: 589-593.

O'Meara GF, Gettman AD, Evans Jr LF, Scheel FD 1992. Invasion of cemeteries in Florida by Aedes albopictus. J Am Mosq Control Assoc 8: 1-10.

PAHO 1995. Dengue y Dengue Hemorrágico en las Américas: Guías para su Prevención y Control, Organización Panamericana de la Salud, Publ. Cient. no. $548,109 \mathrm{pp}$.

Reiter P 1996. Oviposition and dispersion of Aedes aegypti in an urban environment. Bull Soc Pathol Exot 89: 120-122.

Sabattini MS, Avilés G, Monath TP 1998. Historical, epidemiological and ecological aspects of arboviruses in Argentina: Flaviviridae, Bunyaviridae and Rhabdoviridae. In APA Travassos da Rosa, PFC Vasconcelos, JFS Travassos da Rosa (eds), An Overview of Arbovirology in Brazil and Neighbouring Countries, Instituto Evandro Chagas, Belém, p. 113134.

Schultz G 1989. Cemetery vase breeding of dengue vectors in Manila, Republic of the Phillipines. $J$ Am Mosq Control Assoc 5: 508-513.

Schweigmann NJ, Orellano P, Kuruc J, Vera MT, Méndez A 1996. Presencia generalizada de Aedes aegypti (L.) (Diptera: Culicidae) en la Ciudad de Buenos Aires. IV Congreso Argentino de Entomología, Mar del Plata, Argentina, p. 297.

Service MW 1992. Importance of ecology in Aedes aegypti control. Southeast Asian J Trop Med Public Health 23: 681-690.

Tinker ME 1964. Larval habitat of Aedes aegypti (L.) in the United States. Mosq News 24: 426-432.

Tun-Lin W, Kay BH, Barnes A 1995. The premise condition index: a tool for streamlining surveys of Aedes aegypti. Am J Trop Med Hyg 53: 591-594. 
472 Ae. aegypti in Cemeteries of Buenos Aires - Darío Vezzani et al. 